\title{
Open access in the world and Latin America: A review since the Budapest Open Access Initiative
}

\author{
Acesso aberto no mundo e na América Latina: \\ uma revisão a partir da Budapest \\ Open Access Initiative
}

Michelli Pereira da COSTA'

Fernando César Lima LEITE’

\begin{abstract}
In 2012, the Open Access Movement to scientific information celebrated ten years of existence. The period, which represents the first stage of consolidation of the movement, has been analyzed to allow the planning of new phases. With the purpose of providing tools and contributing to these discussions, the article addresses the historical aspects of the international and regional constitution of Open Access Movement. The approach was developed from a descriptive temporal narrative of the main events and initiatives identified in the scientific literature on the subject. The elements discussed in the present study work were organized under two parameters. The first refers to a temporal perspective, defined from the publication of Budapest Open Access Initiative. The second is related to brief discussion of the participation of Latin America. As result, we present a timeline of open access in the world and in Latin America, showing the main aspects covered in the study. The goal of the study is achieved by the proposed systematization as we analyze the open access initiatives in Latin America and establish how they influenced and were influenced by other regions of the world.
\end{abstract}

Keywords: Latin America. Open access. Scientific information.

\section{Resumo}

Em 2012 o Movimento de Acesso Aberto à informação científica comemorou seus dez anos de existência. O período, que representa a primeira fase de consolidação do movimento, tem sido analisado de forma a permitir o planejamento das novas fases. Com a finalidade de instrumentalizar e contribuir para essas discussões o presente trabalho aborda aspectos históricos da constituição do Movimento de Acesso Aberto em nível internacional e regional. A abordagem foi desenvolvida a partir de uma narrativa descritiva temporal dos principais fatos e iniciativas apontadas pela literatura científica sobre o tema. Os elementos tratados neste trabalho foram organizados sob dois parâmetros: o primeiro é referente a uma perspectiva temporal, definida a partir da publicação da Budapest Open Access Initiative; o segundo diz respeito a um recorte regional que destaca a participação da América Latina. Como resultado é apresentada uma proposta de linha do tempo do acesso aberto no mundo e na América Latina, expondo os principais pontos abordados no estudo. A sistematização proposta permite o cumprimento do objetivo desta pesquisa na medida em que analisa as iniciativas de acesso aberto na América Latina e como elas influenciaram e foram influenciadas por outras regiões do mundo.

Palavras-chave: América Latina. Acesso aberto. Informação científica.

\footnotetext{
1 Universidade de Brasília, Faculdade de Ciência da Informação, Programa de Pós-Graduação em Ciência da Informação. Edifício da Biblioteca Central, Entrada Leste, Mezanino, Campus Universitário Darcy Ribeiro, 70910-900, Brasília, DF, Brasil. Correspondence to/Correspondência para: M.P. COSTA. E-mail: $<$ michelli@unb.br>.
}

Received in 10/25/2014, resubmitted on 2/26/2015 and approved in 3/25/2015. 


\section{Introduction}

The process of scholarly communication is constantly changing. The changes mainly occur due to social contexts and technological advances. According to Meadows (1999), the most significant changes occurred as the result of the emergence of journals in the mid-seventeenth century, scientific societies in the eighteenth century, professionalization of research and expertise in areas of knowledge in the nineteenth century and, more recently, the emergence of the electronic world in the twentieth century.

Together with the factors that caused changes in the previous centuries, two other combined elements caused significant changes in the system of scholarly communication in the twenty-first century. The first one is related to the dissatisfaction of researchers with the traditional model of scholarly publication that limits access to their research outputs. The second, in turn, is the emergence of opportunities for expediting and streamlining communication processes, provided by the latest technologies, which had already been incorporated into the world of scholarly communication since the last century. These two factors, the dissatisfaction of researchers and technology, fueled the emergence of open access initiatives.

Open Access (OA) Initiatives are related to two strategies. One of them, known as the gold road, encourages the scholarly publishing in open access journals. The other, called green road, aims to develop digital open access repositories from which the publications, or papers accepted for publication, are alternately distributed. Both strategies have been strengthened through the establishment of Open Access.

The movement began with the articulation of researchers and institutions mostly in northern countries. However, the perspective is timely for countries socially and historically excluded from the center of science. Among the benefits of open access, the most significant one is that researchers from institutions that cannot afford to pay for the subscriptions to commercial journals and databases can access the literature. In addition, it is expected that initiatives increase the visibility of open access literature.
Regarding production, dissemination and access to scientific knowledge, when compared with other regions, Latin America has unique characteristics that favor the adoption of open access. This relationship has been pointed out by authors such as Chan and Costa (2005), Alperin et al. (2008) and Babini (2011).

Chan and Costa (2005) highlight the importance of access to Science and Technology (S\&T) to reduce the problems of developing countries, as it is the case of Latin American countries. According to these authors, these countries are on the fringe of S\&T production due to low investment in research and the difficulties to access international scholarty literature because of the high cost of subscriptions to main journals. The authors, Chan and Costa (2005) presented data from 2004, published by the World Health Organization (WHO), showing that $56 \%$ of countries with Gross Domestic Product (GDP) below $\$ 1,000$ did not subscribe to the main journals from 1999 to 2004. Given this reality, according to Chan and Costa (2005), open access has been the key element for significant changes in scholarly communication, as it provides more equitable access to scientific publications and includes the participation of researchers from developing countries in the "global knowledge commons", i.e., a global public good.

Alperin et al. (2008), in turn, draw attention to the amount of open access journals published in Latin America, particularly in Brazil. According to the data from Directory of Open Access Journals (DOAJ) in October 2013, Brazil is the second country with the highest number of open access journals (Directory of Open Access Journals, 2013). However, the authors point out that the reasons that led to the growth of open access in the region are different from those from the northern countries. This is because journals are traditionally free in the region, not having large commercial publishers such as those in North American and European countries. Thus, for Latin America, the advent of information technology and open access initiatives means a chance to establish the necessary infrastructure to expand the dissemination of scientific production as it has never focused on profit.

Babini (2011) points out, among other things, the development of Institutional Repositories in the region. According to this author, in Latin America, institutions producing scientific knowledge, universities and research 
institutes consider these systems an "adequate choice" to manage and give visibility to institutional scientific production. In addition, some governments, such as those in Argentina, Brazil, Peru and Mexico, have supported institutional repositories.

Open access contributes to scientific development through the optimization of some of the processes and promotes opportunities for other regions to participate in international scholarly communication. Among the new regions, Latin America has shown a strong inclination for open access. Therefore, considering the characteristics and opportunities discussed so far, the aim of the present study was to analyze the open access initiatives in the region and discuss how they have influenced and were influenced by initiatives from other regions of the world.

\section{Methods}

We adopted the bibliographic research method to meet the research objective as suggested by Lima and Mioto (2007, p.38). According to these authors, this type of research "implies an ordered set of procedures to find solutions, respecting the object of study" (our translation) ${ }^{2}$. To conduct the study, the authors propose the four following parameters to analyze the literature: the subject, linguistic, chronological parameters, and parameter of the sources.

For the subject and linguistic parameters, we selected studies written in English, Portuguese and Spanish that dealt mostly with the historical elements of the Open Access and that presented evidence of the participation of Latin America. Scopus and Google Scholar were used as the source to collect the data. We choice these two databases because they are widely used as new sources for bibliographic metrics, as discussed by Meho and Yang (2006). According to these authors, both databases have been considered alternative and complementary tools to the traditional and inflexible tools such as the Web of Science.

We conducted a keyword search for the terms "history" + "open access" + "Latin America" in Portuguese, English and Spanish in the two databases. In Google
Scholar we added the parameter filetype:pdf, so that the recovery system gave preference to PDF files. The application of search strategies resulted in 4,914 documents in Google Scholar and 56 in Scopus.

A preliminary reading of the selected texts allowed the identification of citations from other relevant authors whose studies were included in the analysis. The studies considered as data source for the research included the following documents: Harnad (1994), Harnad (2001), Odlyzko (2002), Sarmento et al. (2005), Askey (2006), Civallero (2006), Bailey (2007), Alperin et al. (2008), Murray-Rust (2008), Barros (2012), Budapest Open Access Initiative (2012), Mishra (2012), Suber (2012).

Based on these studies, we prepared a historical description of the main relevant facts that contributed to the establishment of open access in the world, highlighting the actions in Latin America. The global and regional parallel is illustrated in the Open Access Timeline in the world and in Latin America, shown at the end of the article. Next, we report the results.

\section{Historical perspectives of open access}

Open access is free and unrestricted availability of complete scholary publications on the Internet. Its consolidation in the world has been favored by international open access endeavors. The expression 'open access' was first used for this purpose by the Budapest Open Access Initiative (BOAI) (Budapest Open Access Initiative, 2002) which will be used, therefore, as a framework for the discussion of open access in the paper. For this reason, the historical perspective of open access will be organized into three periods: before BOAI, BOAI and after BOAl.

Before BOAl: Despite the BOAl being considered a landmark document for $\mathrm{OA}$, it was not the first initiative to discuss the nuclear idea of open access. Sarmento et al. (2005) highlight three previous documents that are the result of meetings held at the World Conference on Science for the twentieth century. The first one, the "Santo Domingo Declaration"(Acordo..., 2002), points out that science should be available to everyone and that, therefore, the infrastructure capacity of information

\footnotetext{
2"implica em um conjunto ordenado de procedimentos de busca por soluções, atento ao objeto de estudo".
} 
technologies and communication of science need to be increased to be accessible to the society. The second, the "Declaration on science and the use of scientific knowledge" and third documents, "An agenda for science", emphasize the need for sharing scholarly information, especially when produced with public funds, recognizing that access to this information is essential for the advancement of science itself. According to Sarmento et al. (2005, p.3, our translation), these documents are relevant when considering the context in which the movement arised, as they emphasize the creation of "a new social contract for science, highlighting the components of science and society, and innovation to ensure the development of concrete initiatives for international scientific cooperation"3.

Referring to the years before 1999, Civallero (2006) also points out other initiatives. The author considers the ArXiv repository as the first relevant attempt developed in 1991. According to Ramlo (2007), the repository was developed by Paul Ginsparg under the name LANL Preprint Archive, referring to the institution, the Los Alamos National Laboratory (LANL), that hosted it. When Ginsparg left the LANL, the repository was then hosted at Cornell University, storing open access literature in the field of physics and related sciences.

Following the development of ArXiv, Civallero (2006) points out the meeting held in 1992, organized by the Association of Research Libraries (ARL) through the initiative Scholarly Publishing and Academic Resources Coalition (SPARC), which discussed literature in the electronic format. On this occasion, the new context of treatment and use of scientific publications in electronic media were discussed. Given the development of open file systems and the new scenario, Stevan Harnad published a study entitled "The subversive proposal" in 1994, which systematized the idea of self-archiving. The development of this idea resulted in what the OA later called the green road strategy.

In 1999, the Santa Fe Convention was held in the United States in the same year as the declarations were published on Science. The goal, according Lagoze and Van de Sompel (2001), was to discuss the opportunities for using the web for scientific information systems to promote greater dynamism and speed in communication. This meeting resulted in the organization of the Open Access Initiative (OAI), whose essence lies in the use of the Open Archives Initiative Protocol for Metadata Harvesting Protocol (OAI-PMH). This communication protocol allows systems to share metadata (data describing the information resources) without intermediate processes. This initiative was important for the development of open access information systems because it established standards and a protocol to guide and ensure interoperability between systems, one of the building blocks for the promotion and visibility of scientific literature in the open access environment.

Between 2000 and 2001 other meetings including scientists and information professionals were held to discuss the issue of science and access to their results. As a result of these events, the declarations were published and we discuss them below. The open letter from the Public Library of Science (PLOS) and the document "Declaring Independence", published by SPARC, were the most outstanding because these were related to important institutions that promote open access.

The PLoS declaration is an open letter from some academic institutions in the field of Biomedical Sciences. It states its support to the development of an online public library that provides full texts of scientific publications. To this end, the signatories commit themselves to publish only in journals that allow free and unrestricted redistribution of publications in PubMed Central (PMC) or other similar information services. The PMC is a repository that was developed in 1999 by the National Institutes of Health (NIH) to store and disseminate manuscripts and published research in the field of Health Sciences (Pontika, 2011). This is another example of successful open access initiative whose genesis precedes the BOAl.

The document "Declaring Independence", in turn, is a letter addressed to researchers, but signed by only one of them: Michael Rosensweig. Although the letter was signed by a single researcher, it was published by

\footnotetext{
3 "um novo contrato social para a ciência, destacando os componentes de ciência e sociedade, e de inovação de forma a garantir o desenvolvimento de iniciativas concretas para a cooperação científica internacional".
} 
SPARC and the Triangle Research Libraries Network (TRLN), major international organizations of the scientific community. One of the key arguments is the discussion of access to scientific information related to the serial crisis. The author first draws attention to the fact that their research is being sold by commercial publishers, with increasing for-profit plans, and states that subscriptions are far too costly for libraries. According to Figure 1, provided between 1986 and 1998, a journal subscription in evolutionary ecology increased approximately $\$ 800.00$ per year, reaching a $75 \%$ profit margin. Based on this argument, the author cites the experience of developing an 'independent' journal in the field, created as an alternative to the commercial model.

Pre-BOAl initiatives in Latin America shared concerns about the limited access to scientific information and the interest in using the Internet to speed up and democratize the dissemination of information. We highlight three of these initiatives. The first, in chronological order, is the "Declaración of San José hacia la Biblioteca Virtual en Salud", 1998. In this document, the Centro Latino-Americano e do Caribe de Informação em Ciências da Saúde were committed to developing the Virtual Health Library (VHL) to increase access to information in the field. The VHL, which was established in the same year as the declaration, according to its own conception, is a scientific and technical information system to promote the production and use of information sources in electronic format through the Internet to promote direct and universal access.

In 2001, the "Declaration of Havana towards equitable access to Health Information" again highlights the responsibility of the state regarding the access to information. In this declaration, the participants of the VHL meeting classified the scientific information in the field as a global public good and highlighted the need for national and international policies to ensure access and dissemination. Thus, it reiterated its commitment to the development of the $\mathrm{VHL}$.

In addition to the $\mathrm{VHL}$, the development of the Scientific Online Electronic Library (SciELO) was released in 1997. SciELO indexes journals supported by the Fundação de Amparo à Pesquisa do Estado de São Paulo (FAPESP, State Research Support Foundation) and Bireme. The indexed journals consist of full texts from journal collections that are available for free. According the data from SciELO in 2013, the system has journal collections from eleven countries, among which eight are from Latin America.

All these events, documents and systems were important for the initial consolidation of OA. Therefore, the number of initiatives and the arguments that were used at the time to discuss alternatives to ensure broad access to scientific publications were present during the preparation of the $\mathrm{BOAI}$.

Budapest Open Access Initiative: Based on the aforementioned discussions and initiatives, a meeting was held in Budapest in 2001 and the BOAl document was published in February 2002 (Budapest Open Access Initiative, 2002). The document raises the issue of scientific communication in the contemporary context and considers that the processes of traditional communication through journals must be influenced by new technologies and the Internet. The positive influence in this context is understood as the electronic distribution of full texts from peer-reviewed journals through the Internet and without access restrictions. By discussing the concept of open access, it is claimed, from prior experience, that this model is possible. Experiences are not individually listed, but it is pointed out that the different initiatives were still providing an "extraordinary power"to readers as they could find and use the relevant literature. Moreover, according to the Declaration, the studies available in open access systems and the authors gain more visibility, readership and impact.

The advantages cited by the $\mathrm{BOAI}$ are recurrently used to demonstrate the benefits of open access. In the document available on the Internet, the advantages (visibility, readership, and impact) are hyperlinked to other texts that discuss the issue. The first text that received a hyperlink in BOAI was Harnad's article (Harnad 2001), which addresses issues related to access, impact and assessment of publications. The author states that the purpose of researchers is to publish their articles to impact their research and not the sale of publications, as they are'rewarded'by universities and funding agencies that assess the impact of what they produce. Thus, when the results of their studies are publicly accessible, it increases the impact factor, which is the interest of researchers and institutions. 


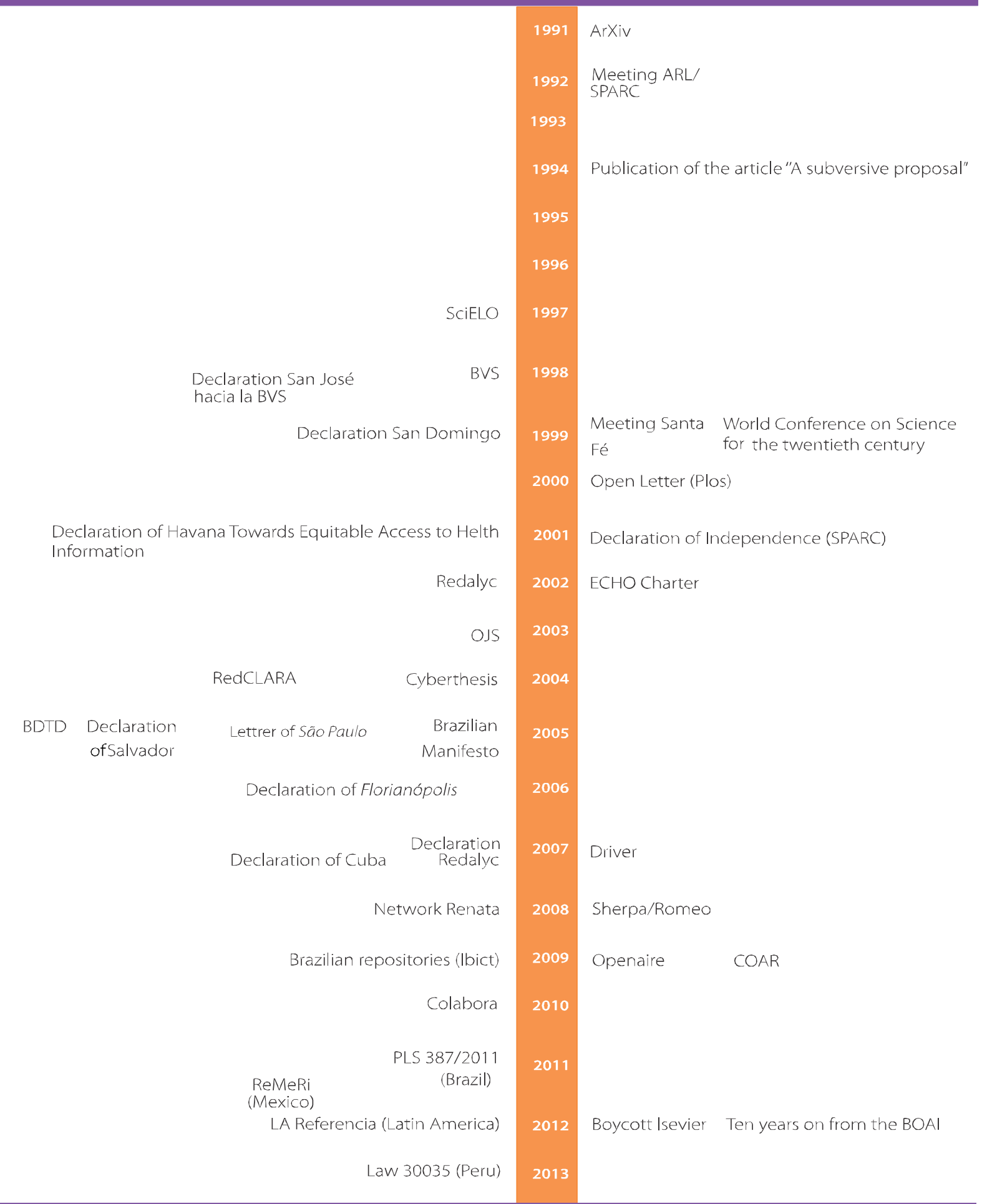

Figure 1. Timeline of open Access in the world and Latin America.

Source: The authors (2014).

Note: ArXiv: e-print service in the fields of physics, mathematics, computer science, quantitative biology, quantitative finance and statistics; BOIA: Budapest Open Access Initiative; BDTD: Brazilian Digital Library of Theses and Dissertations; BVS: Biblioteca Virtual em Saúde; COAR: Confederation of Open Access Repositories; ECHO: Cultural Heritage Online; OJS: Open Journal System; PL: Projeto de Lei (Brazil); PLS: Projeto de Lei do Senado (Brasil) SNRD: National System of Digital Repositories (Argentina) SPARC: Scholarly Publishing and Academic Resources Coalition. 
In addition to the advantages of open access, Harnad (2001) also shows that online self-archiving of peer-reviewed production in institutional systems is strategic. However, the author emphasizes that self-archiving most be termined by institutions the successful. Harnad raises the discussion about the need for institutional open access policies, which are formal instruments that states the institution's position regarding the treatment of its scientific production.

The second and third hyperlinks in Budapest Open Access Initiative (2002) lead to an error page, which does not allow the identification of the texts. Attempts to access the hyperlink were held in July and August 2013. The term 'impact' is the fourth hyperlink to paper of Odlyzko (2002), which addresses the evolution of scholarly communication. The trend towards the use of online content is one of the factors addressed by the author to demonstrate the impact that the new dynamics of communication could have. According to the data presented in the article, the use of these contents has steadily increased. As an example of this trend, the author cites the emergence of electronic theses and dissertations and the experience of SciELO, whose visibility increased from 5,000 pages in 1999 to 64,000 in 2000. Despite the high growth rates of access to this system, the author argues that this does not represent the same quantity of access when compared to printed publications, even though it was close.

After discussing the advantages of open access, Budapest Open Access Initiative (2002) invites individuals and institutions to cooperate by making academic literature available in open access. Therefore, the declaration determines which licenses should be granted for publications in this context, considering that the only restriction that should be given to authors is the control of integrity of their work and the right to be duly cited.

In order to achieve the goals, the Budapest Open Access Initiative, (2002) proposed two strategies: selfarchiving and the development of open access journals. Self-archiving means that the authors can upload a copy of their peer-reviewed publications in open access repositories, which must in agreement with the OAl standards. This suggestion was later known as the green road strategy. The second strategy suggests a change in the business model of existing journals and the development of open access journals, which should seek other forms of revenue instead of charging for access to their content. The implementation of these guidelines regarding the journals was later known as the golden road to open access.

The Budapest Open Access Initiative (2002) raises the problem of access to scholarly communication and points out strategies for a joint action. To validate the document, the declaration was signed by 17 university researchers, research centers and publishers in North America and Europe and therefore, according to Sarmento et al. (2005), the scientific community became committed to open access.

Furthermore, BOAI was, according to its new statement published ten years later (Budapest Open Access Initiative, 2012), the first international action to receive significant funding for the development of strategies. However, the document does not specify how much funding it was received or who provided it.

All these factors show how BOAl was a key element for the OA discussions. According to Sarmento et al. (2005, p.4), "as the document presents some principles, strategies and a statement of commitment, it has become the most important document in the open access movement" (our translation) ${ }^{4}$. In addition, the BOAI is widely cited in documents that succeed it and its guidelines are observed when developing open access systems.

After BOAl: The following year after the publication of BOAl in 2003, two other declarations with significant importance to OA were published, as pointed out by Sarmento et al. (2005). The importance of these two declarations together with $\mathrm{BOAl}$ are also highlighted by other authors who discuss the issue such as Askey (2006), Bailey (2007), Murray-Rust, (2008), Mishra (2012) and Suber (2012).

One of these documents was the Bethesda Statement on Open Access Publishing (Bethesda..., 2003). which was prepared during a meeting of the Howard Hughes Medical Institute in Maryland, United

\footnotetext{
4 "esse documento por apresentar alguns princípios, estratégias e uma afirmação de compromisso, torna-o um dos mais importantes documentos do movimento acessolivre".
} 
States. The objective was to stimulate a debate on open access in the research community of Biomedicine and try to come to an agreement on the issue by involving all parties of the scientific communication process. In addition to the proposed activities, the statement establishes two conditions for a publication to be understood as open access. The first is the author's permission granting the users a license to copy, use, distribute, transmit, display and to make and distribute derivative works. The second is the immediate filing of a copy of the publication in an online digital repository of a research institute or organization so that it is agreement with the standards of interoperability and preservation. Under these conditions, the statement highlights the PMC repository as the repository for the area of Biomedical Sciences.

The second document is the Berlin Declaration on Open Access to Knowledge in the Sciences and Humanities (Berlin..., 2013), signed by research organizations and researchers from different countries. An important aspect of the Berlin Declaration is the explicit expansion of benefits and the need for open access in areas of knowledge related to social sciences and humanities. The statement claims to be in agreement with the BOAl, the ECHO Charter and the Declaration of Bethesda. Its goal is to encourage researchers to publish in open access, support the transition to a new paradigm in scientific communication, encourage open access publications and advocate for them to be recognized for academic evaluation purposes. The latter objective emphasizes the significance of funding agencies to consolidate the actions of open access.

In addition to the above-mentioned declarations, other ones were released, strengthening the OA movement. These new documents followed the pattern of the previous declarations: they were documents of researchers who were participating in an academic event and that is why they received the names of cities or regions that hosted these meetings Valparaiso Declaration for Improved scientific Communication in the Electronic Medium, 2004 (Valparaiso..., 2004); Washington DC Principles for Free Access to Science, 2004 (Washington DC, 2004); Brussels Declaration on Open Access, 2012 (Brussels..., 2012); Croatian Open Access Declaration, 2012 (Croatian..., 2012). Other documents were related to the commitment of institutions to the issue (Scottish
Universities Declaration on Open Access, 2005 (Scottish..., 2005); OECD Principles and Guidelines for Access to Research Data from Public Funding, 2007 (Organisation for Economic Co-operation and Development, 2007); IFLA Statement on open access - clarifying IFLA's position and strategy, 2011 (International Federation of Library Association and Institutions, 2011); COMMUNIA International Association on the Public Domain Position on EC Horizon 2020 Open Access policy, 2012 (Communia International Association on the Public Domain, 2012); Recommendation for Open Access and Online Content in LILACS, 2012 (Recommendation..., 2012). The documents mostly presented open access and provided an explanation of the reasons why it is important to develop actions that promote broad access to scientific information and they all ended with the commitments and strategies to achieve the goal.

In 2012, the BOAl celebrated ten years of existence and published a new document, "Ten years on from the Budapest Open Access Initiative: setting the default to open" (Budapest Open Access Initiative, 2012, online). In this edition, they reaffirmed the strategies proposed by BOAl: the green road to open access archives and the golden road to open access journals. Additionally, they presented new recommendations for the next ten years for the use of open access policies by institutions producing scientific knowledge, licensing of open access content, sustainability, coordination of initiatives and the promotion of open access systems.

In the same year that the BOAl celebrated ten years, a new great movement of scientists took place worldwide to demand open access to scientific literature. This movement began with the proposition of the researcherTimothy Gowers to boycott Elsevier, which by the end of 2014 would have a total of 15,000 subscribers. The purpose of the boycott, according to Barros (2012), was due to the support given by the publisher to the US bill that reversed the $\mathrm{NIH}^{\prime}$ s access policy, failing to promote open access to publications that report the results of research funded with public funds. As a result of the boycott, according to the author, ten publishers resigned from Elsevier, the support for the bill was withdrawn, and a new bill promoting open access has been gaining momentum in the United States. 


\section{Open access in Latin America}

In Latin America, discussions and systems have taken place around the issue long before the Budapest Open Access Initiative (2002), as previously explained. In the post-BOAl period, the strongest initiative in favor of open access was the Brazilian Manifesto to Support Open Access to Scientific Information (Instituto Brasileiro de Informação em Ciência e Tecnologia, 2005). The manifesto was released by the Instituto Brasileiro de Informação em Ciência e Tecnologia (IBICT, Brazilian Institute of Information in Science and Technology) in 2005. The terms of the Berlin Declaration were used in the manifesto, referring to ways of publication and conditions for open access. That said, the Manifesto highlights the need for the participation of academic institutions, researchers, funding agencies, commercial and non-commercial publishers. After citing the actions that each of those involved should take into consideration, the Manifesto ends by pointing to the importance of creating a national policy to ensure the compliance with these actions.

In 2005, the "Salvador Declaration on Open Access: the perspective of developing countries" (Declaração..., 2005) was published. It was prepared by the participants of the International Seminar on Open Access. The document emphasizes the expectation of increase in open access in developing countries and, as a result of this, the possibility of researchers to access literature and science. Further, they present the claims of the signatories for the scientific policies.

Later in 2005, the "São Paulo Letter"was published, which is a manifestation of support for OA. The Letter presents arguments that support the open access proposal, among them the idea that access to scientific literature is essential to scientific and social advancement. In order to assure access, sixteen recommendations are suggested for consideration and include the strategies proposed by BOAI and its progress.

The Declaration of Florianópolis was drafted in 2006 by Brazilian researchers in the field of psychology to express their support for open access to peer-reviewed literature. This document makes a reference to the concept of open access of Bethesda (2003) and several recommendations are suggested to reach their goals.
Many other documents were released in Latin America with the same purpose. We highlight the Declaración de Cuba en favor del acceso abierto, 2007 (Declaración..., 2007). The document refers to the terms used by BBB, Salvador and Florianópolis. The declaration invites researchers to make their work available in institutional repositories and open access digital libraries and highlights the Biblioteca Virtual de la Unioin Latinoamerica de Entidades de Psicologiia (BVS ULAPSI).

The Bill no 1120, from 2007 (Brasil, 2007), was submitted to the Brazilian Congress. The bill proposes the creation of a national law for mandatory development of IR by the higher education institutions and public research centers. The goal of the bill was the development of IR and the mandatory publication of a copy of the studies produced by researchers who received public funding. The bill received a favorable committee report, with some observations, but in 2011 it was filed because it had been in Congress for four years and did not come up for consideration on the floor (Brasil, 2007). In the same year, it was replaced by the Senate Bill no 387, 2011 (Brasil, 2011). Its main content is identical to the 2007 bill (Brasil, 2007), but it has further specifications such as the type of documents to be deposited and the time between the publication and deposit. The bill has not yet been approved, but according to the Portal of Legislative Activity of the Senate, it is in progress in various agendas of the committees.

A similar initiative was identified in Argentina. In 2011, the National System of Digital Repository (SNRD) was created through a ministerial resolution. Its purpose was to create an interoperable network of digital repositories, through the establishment of policies, standards and common protocols (Argentina, 2011). In the same year, a bill was drafted, which was sanctioned in 2012, to ensure the development of IR in institutions that receive public funding and the deposit of copies of peer-reviewed published or non-published works. The novelty of this bill in relation to the Brazilian one is the specification for the treatment of primary data of the research.

In Mexico, also in 2011, the Red Mexicana de Repositories Institucionales (ReMeRI) was created, which has an integrated search system among the IR and offers training workshops and development tools. As the Argentine system, some standards are required to join 
the Mexican network, which are diagnosed through a validation instrument (Jiménez, 2013).

In 2012, the Red Federada Latinoamericana de Repositorios Institucionales de Documentación Científica en América Latina (LA Referencia) was launched, with the support of RedCLARA and the sponsorship of the Regional Fund of Public Goods of the Inter-American Development Bank (BID). Its goal was to promote the creation of a regional strategy for IR. Toward that end, issues related to agreements, regional policies and the definition of standards were established (Babini, 2011). In May of that year, Latin America, through the LA Referencia, joined the Confederation of Open Access Repositories (COAR), as disclosed on their website (Red Federada Latinoamericana de Repositorios Institucionales de Documentación Científica en América Latina, 2014). The confederation is an association of academic institutions and research of European, Asian, North American and Latin American countries that aims to strengthen the global networks of open access repositories.

The following year, in 2013, a bill for open access was approved in Peru. The bill no 30035 (Peru, 2013), regulates the Repositorio Nacional Digital de Ciencia, Tecnología y Innovación de Acceso Abierto. The repository in question is characterized as a 'central site' where digital information related to the production of science, technology and innovation in the country is stored. Its use is intended for researchers affiliated to state agencies, researchers who have received public funding and researchers who wish to make their production available for open access.

National laws such as these are certainly powerful allies to ensure the establishment and/or consolidation of mechanisms that promote open access. In the case of the bills in Latin America, the green road strategy was preferred. Some OA scholars, such as Suber (2009), argue that the institutional performance is better if green road strategy is used. This is because the right of researchers to publish wherever they want is ensured, with the later commitment to deposit a copy in open access repositories, according to the agreement with the publishers.

In Latin America, performance networks were developed to implement IR that complies with international standards of interoperability and preservation. The development of works in repository networks can facilitate resource sharing, allow higher quality for the exchange of data and provide more visibility of the scientific production. The IR networks identified in the region were as follows: Comunidade Colabora, LA Reference, SNRD and ReMeRI.

The performance of Latin America in regional networks can beexplained due to the specific characteristics of the region, which differs from countries in North America and Europe. When discussing these specificities, Alperin et al. (2008) present data showing the growth in the infrastructure of the region in comparison with other regions. However, the growth has not been enough to ensure a good infrastructure for information systems, as the Internet was available to only $22.1 \%$ of the population until 2008.

In addition to the issue of infrastructure in the region being an obstacle to building stronger mechanisms of dissemination of science produced here, the historical and social formation is marked by challenges. These elements must be considered when dealing with science produced in the region, as they are the structure of the system. According to Zuñiga (1986), in developing countries, and particularly in Latin America, the reality of S\&T is closely tied to its historical entirety. Therefore, to understand the context one needs to see the wider picture, which includes the resources available and the historical and cultural aspects.

\section{Conclusion}

The development and consolidation of open access has been occurring differently in developed countries and the rest of the world, particularly in Latin America. This difference is due to, among other things, the characteristics of the scholarly communication system established in Latin America over time. On the one hand this system was not capable of enhancing scientific development, on the other hand, open access, especially the golden road - due to the low presence of prestigious scientific commercial publishers - has significantly advanced in the region. This finding comes from successful initiatives such as SciELO and widespread adoption of the Open Journal System (OJS). The experience of SciELO is cited in one of the BOAl 
documents, showing that the initiative was in the forefront and influenced the development of OA.

Despite this Latin American reference, the consolidation of the golden road in Latin America, due to the non-commercial nature of most of the scientific publishers in the region, has not been enough to boost the green road. Now, we suppose that because most of the scientific publishers are oblivious to the market logic, most scientific journals do not impose barriers to redistribution of scientific literature by them in alternative media, such as institutional repositories.

We observed that the development of institutional repositories in some countries in the region has been accompanied by debates and bills in the public sphere and thus, a parallel of open access initiatives in Latin America can be traced with other regions of the world. However, despite the recent advances of the green road, particularly the increase in the number of institutional repositories and the intensification of cooperative work in the region, there is still much to be achieved in this area.

\section{Colaboradores}

Todos os autores contribuíram na concepção e desenho do estudo, análise de dados e redação final.

\section{References}

Acordo: declaração de Santo Domingo. Santo Domingo, 2002. Disponível em: <http://segib.org/reuniones/files/2002/06/IVConferencia-Ibero-americana-de-Ministros-da-AdministraçaoPublica-e-Reforma-do-Estado-Acordo.pdf>. Acesso em: 1 dez. 2013.

Alperin, J.P., Fischman, G.E., Willinsky, J. Open access and scholarly publishing in Latin America: Ten flavours and a few reflections. Liincem Revista, v.4, n.2, p.172-185, 2008. Available from: <http://revista.ibict.br/liinc/index.php/liinc/article/ viewFile/269/167>. Cited: Jan. 1, 2013.

Argentina. Resolução Ministerial n469, de 17 de maio de 2011. Aprova a revisão 4 dos módulos 1 e 8 e a revisão 5 do módulo 6 dos procedimentos de distribuição de energia elétrica no sistema elétrico nacional. Disponible en: <http://www. biblioteca.mincyt.gob.ar/docs/res_be_469-11.pdf>. Acceso en: 1 ene. 2013.

Askey, D. Moving beyond the MLA \& deviant modes of scholarly communication. In: Women in German Conference, 2006, Snowbird. Proceedings electrônicos... Snowbird: Kansas State University, 2006. Available from: <http://hdl.handle.net/2097/ 701>. Cited: Jan, 1. 2013.

Babini, D. Acceso abierto a la producción científica de América Latina y el Caribe: identification of main institutions for regional integration strategies. Revista lberoamericana de Ciencia Tecnologia y Sociedad, v.6, n.17, p.31-56, 2011. Disponible en: <http://hdl.handle.net/10760/15574>. Acceso: 1 ene. 2013.

Bailey, C. Open access and libraries. Collection Management, v.32, n.3-4, p.351-383, 2007. Available from: <http://digitalscholarship.org/cwb/OALibraries2.pdf>. Cited: Jan. 1, 2013.

Barros, M. A primavera acadêmica e o custo do conhecimento. Liinc em Revista, v.8, n.2, p.365-377, 2012. Disponível em: <http:// revista.ibict.br/liinc/index.php/liinc/article/view/486>. Acesso em: 1 fev. 2013.

Berlin declaration open access to knowledge in the sciences and humanities. Berlin: Open Access, 2003. Available from: <http:// oa.mpg.de/lang/en-uk/berlin-prozess/berliner-erklarung/>. Cited: Feb. 1, 2013.

Bethesda statement on open access publishing: Meeting on open access publishing. Bethesda, 2003. Available from: <http:// legacy.earlham.edu/ peters/fos/bethesda.htm>. Cited: Feb. 1,2013

Brasil. Projeto de lei 1.120, 21 de maio de 2007. Dispope sobre o processo de disseminação da produção teìcnico-cientiifica pelas instituições de ensino superior no Brasil e daì outras providências. 2007. Disponível em: <http://www.camara. gov.br/proposicoesWeb/fichadetramitacao?idProposicao= 352237>. Acesso em: 1 fev. 2013.

Brasil. Projeto de lei do Senado 387, 5 de julho de 2011. Dispõe sobre o processo de registro e disseminação da produção técnico-científica pelas instituições de educação superior, bem como as unidades de pesquisa no Brasil e dá outras providências. 2011. Disponível em: <http://www. senado.gov.br/atividade/Materia/Detalhes.asp?p_cod_ mate $=101006>$. Acesso em: 1 fev. 2013.

Budapest Open Access Initiative. Read the Budapest open access initiative. Budapeste, 2002. Available from: <http://www. opensocietyfoundations.org/openaccess/read>. Cited: Feb. 1, 2013.

Budapest Open Access Initiative. Ten years on from the Budapest Open Access Initiative: Setting the default to open. Budapeste: BOAl, 2012. Available from: <http://www. opensocietyfoundations.org/openaccess/boai-10recommendations>. Cited: Feb. 1, 2013.

Brussels declaration on open access. Brussels, 2012. Available from: <http://openaccess.be/2012/10/22/brussels-declara tion-on-open-access/>. Cited: Feb. 1, 2013.

Chan, L; Costa, S. Participation in the global knowledge commons: Challenges and opportunities for research dissemination in developing countries. New Library World, v.106, n.3/4, p.141-163, 2005. Available from: <http://www. 
emeraldinsight.com/doi/full/10.1108/03074800510587354>. Cited: Feb. 1, 2013.

Civallero, E. Open access: Experiencias latinoamericanas. In: Congreso Internacional de Bibliotecología e Información, 2., 2006, Lima. Anales electrónicos... Lima: Colegio de Bibliotecólogos del Peru, 2006. Disponible en: <http://hdl. handle.net/10760/11621>. Acceso en: 1 ene. 2013.

Communia International Association on the Public Domain. Position on ec horizon 2020 open access policy. Brussels, 2012. Available from: <http://www.communia-association.org/ 2012/11/20/position-on-ec-horizon-2020-open-accesspolicy/>. Cited: Feb. 1, 2013.

Croatian open access declaration. Zagreb, 2012. Available from: http://www.fer.unizg.hr/oa2012/declaration. Cited: Feb, 1. 2013.

Declaração de Salvador sobre o acesso aberto: a perspectiva dos países em desenvolvimento. International Seminar on Open Access. Salvador, 2005. Disponível em: <http://www. icml.org/channel.php?lang=pt\&channel=86\&content $=428>$. Acesso em: 1 dez. 2014.

Declaracioin de Cuba en favor del acceso abierto. In: Congreso de la Unión Latinoamericana de Entidades de Psicología, 2., 2007, Havana. Anales electrónicos... Havana: Sociedad Cubana de Psicología de la Salud, 2007. Disponible en: <http:// promociondeeventos.sld.cu/ psicosalud/declaracion-decuba-en-favor-del-acceso-abierto/>. Acceso en: 1 dic. 2013.

Directory of Open Access Journals. DOAJ Statistics. [s...], 2013. Available from: <https://doaj.org/>. Cited: Oct. 1, 2013.

Harnad, S. A subversive proposal. In: Okerson, A.; O’Donnell, J. (Ed.). Scholarly Journals at the Crossroads: A subversive proposal for electronic publishing. Washington: Association of Research Libraries, 1994. Available from: <http://www.arl.org/scomm/ subversive/toc.html>. Cited: Dec. 1, 2014.

Harnad, S. Research access, impact and assessment. Times Higer Education Supplement, n.18, 2001. Available from: <http:// eprints.soton.ac.uk/255950/>. Cited: Jan. 1, 2013.

Instituto Brasileiro de Informação em Ciência e Tecnologia. Manifesto brasileiro de apoio ao acesso livre à informação científica. Brasília: IBICT, 2005. Disponível em: <http:// livroaberto.ibict.br/docs/Manifesto.pdf $>$. Acesso em: $1 \mathrm{dez}$. 2013.

International Federation of Library Associations and Institutions. Statementon open access: Clarifying IFLA's position and strategy. Haia, 2011. Available from: <http://www.ifla.org/ files/assets/hq/news/documents/ifla-statement-on-openaccess.pdf>. Cited: Feb, 1. 2013.

Jiménez, T. Marco de políticas de acceso abierto para la Red Mexicana de Repositorios Institucionales. Red Mexicana de Repositorios Institucionales. Ciudad De México, 2013. Disponible en: <http://www.remeri.org.mx/remeri/REMERI_ POLITICAS_2013_01.pdf>. Acceso en: 1 feb. 2015.

Lagoze, C.; Van de Sompel, $\mathrm{H}$. The open archives initiative: Building a low-barrier interoperability framework. In: ACM/ IEEE Joint Conference on Digitial Libraries, 1., Roanoke, 2001.
Proceedings electronics... Roanoke: Open Archives Initiative, 2001. p.54-62. Available from: <http://www.openarchives.org/ documents/jcdl2001-oai.pdf>. Cited: Feb. 1, 2013.

Lima, T.; Mioto, R. Procedimentos metodológicos na construção do conhecimento científico: a pesquisa bibliográfica. Revista Katálysis, v.10, n.Esp. p.37-45, 2007. Disponível em: <http://www.scielo.br/pdf/rk/v10nspe/a0410spe.pdf>. Acesso em: 1 dez. 2014.

Meadows, J. A comunicação científica. Brasília: Briquet Lemos, 1999.

Meho, L.I.; Yang, K. A new era in citation and bibliometric analyses: Web of Science, Scopus, and Google Scholar. Journal of the American Society for Information Science and Technology, v.58, n.2, p.297-301, 2006. Available from: <http://arxiv.org/ abs/cs/0612132>. Cited: Dec. 1, 2014.

Mishra, K. Internet a boon for researchers: A study on open access resources. Pragyaan: Journal of Mass Communication, v.10, n.1, p.14-22, 2012. Available from: <http://ims.edu.in/ download-pdf/MJ4077_Pragyaan-MassCommunication.pdf\# page $=20>$. Cited: Dec. 1, 2013.

Murray-Rust, P. Open data in science. Serials Review, v.24, n.1, p.52-64, 2008. Available from: <http://hdl.handle.net/10101/ npre.2008.1526.1>. Cited: Dec. 1, 2013.

Odlyzko, A. The rapid evolution of scholary communication. Learned Publishing, v.15, n.1, p.7-19, 2002. Available from: <http://citeseer.ist.psu.edu/viewdoc/summary? doi=10.1.1.115.7566>. Cited: Jan. 1, 2013.

Organisation for Economic Co-operation and Development. Principles and guidelines for access to research data from public funding. Paris, 2007. disponible dans: <http://www.oecd.org/ sti/sci-tech/38500813.pdf>. Accès: 1 fév. 2013.

Peru. Ley 33.035. Regula el Repositorio Nacional de Ciencia, Tecnología e Innovación de Acceso Abierto. Lima, 2013. Disponible en: <http://www.unesco.org/new/en/communicationand-information/portals-and-platforms/goap/access-byregion/latin-america-and-the-caribbean/peru/>. Acceso en: 1 feb. 2014.

Pontika, N. The influence of the national institutes of health public-access policy on the publishing habits of principal investigators. 2011. Thesis (Doctorate in Philosophy) - School of Library and Information Science, Simmons College, Boston, 2011. Available from: <http://hdl.handle.net/10760/17208>. Cited: Jan. 1, 2013.

Ramlo, S. ArXiv.org and physics education. The Physics Teacher, v.45, n.6, p.374-375, 2007. Available from: <http://scitation. aip.org/content/aapt/journal/tpt/45/6/10.1119/1.2768698>. Cited: em: Cited: Feb. 1, 2015.

Recommendation for open access and online content in LILACS. São Paulo, 2012. Available from: <http://metodologia. lilacs.bvsalud.org/php/level.php?lang=en\&component= 34\&item=55>. Cited: Feb. 1, 2013.

Red Federada Latinoamericana de Repositorios Institucionales de Documentación Científica en América Latina. Inicia el cambio regional: trabajo conjunto para el acceso abierto. 2014. 
Disponible en: <http://lareferencia.redclara.net/rfr/noticias/ inicia-el-cambio-regional-trabajo-conjunto-para-el-accesoabierto>. Acceso en: 1 feb. 2015.

Sarmento, M. et al. Algumas considerações sobre as principais declarações que suportam o movimento Acesso Livre. In: World Congress on Health Information and Libraries, 9., Salvador, 2005. Anais eletrônicos... Salvador: Ministério da Saúde, 2005. Disponível em: <http://hdl.handle.net/10760/ 8512>. Cited: 1 jan. 2013.

Scottish universities declaration on open access. Edinburgh, 2005. Available from: <http://scurl.ac.uk/wp-content/uploads/ 2013/07/ScottishDeclarationOnOpenAccess.pdf>. Cited: Feb. 1, 2013.

Suber, P. Open access policy options for funding agencies and universities. SPARC Open Access Newsletter, n.130, 2009.
Available from: <http://www.earlham.edu/ peters/fos/ newsletter/02-02-09.htm>. Cited: Feb. 14, 2012.

Suber, P. What is open access? In: Suber, P. (Org.). Open access. Cambridge: MIT Press, 2012. p.1-28.

Valparaiso declaration for improved scientific communication in the electronic medium. Valparaiso, 2004. Available from: <http://eprints.rclis.org/20069/>. Cited: Feb. 1, 2013.

Washington DC principles for free access to science. Washington, 2004. Available from: <http://www.dcprinciples. org/>. Cited: Feb. 1, 2013.

Zúñiga, A. Historia de la ciencia y la tecnologia y la realidad de America Latina. Elementos, v.6, n.1, 1986. Disponible en: <http://www.elementos.buap.mx/num06/pdf/17.pdf/>. Acceso en: 1 jan. 2012. 

